\title{
Spatial Variation among Lakes within Landscapes: Ecological Organization along Lake Chains
}

\author{
Patricia A. Soranno, ${ }^{1 *}$ Katherine E. Webster, ${ }^{1,2}$ Joan L. Riera, ${ }^{1}$ \\ Timothy K. Kratz, ${ }^{1}$ Jill S. Baron, ${ }^{3}$ Paul A. Bukaveckas, ${ }^{4}$ George W. Kling, ${ }^{5}$ \\ David S. White, ${ }^{6}$ Nel Caine, ${ }^{7}$ Richard C. Lathrop, ${ }^{1,2}$ and Peter R. Leavitt ${ }^{8}$ \\ ${ }^{1}$ University of Wisconsin, Center for Limnology, 680 N. Park Street, Madison, Wisconsin 53706, USA; ${ }^{2}$ Wisconsin Department of \\ Natural Resources, 1350 Femrite Drive, Monona, Wisconsin 53716, USA; ${ }^{3}$ US Geological Survey Biological Resources Division and \\ Natural Resources Ecology Laboratory, Colorado State University, Fort Collins, Colorado 80523, USA; ${ }^{4}$ Department of Biology, \\ University of Louisville, Louisville, Kentucky 40292, USA; ${ }^{5}$ Department of Biology, University of Michigan, Ann Arbor, Michigan \\ 48109, USA; ${ }^{6}$ Hancock Biological Station, Murray State University, Murray, Kentucky 42071, USA; ${ }^{7}$ Department of Geography, \\ and Institute for Arctic and Alpine Research, Campus Box 450, University of Colorado, Boulder, Colorado 80309, USA; \\ ${ }^{8}$ Limnology Laboratory, Department of Biology, University of Regina, Regina, Saskatchewan S4S 0A2, Canada
}

\begin{abstract}
Although limnologists have long been interested in regional patterns in lake attributes, only recently have they considered lakes connected and organized across the landscape, rather than as spatially independent entities. Here we explore the spatial organization of lake districts through the concept of landscape position, a concept that considers lakes longitudinally along gradients of geomorphology and hydrology. We analyzed long-term chemical and biological data from nine lake chains (lakes in a series connected through surface or groundwater flow) from seven lake districts of diverse hydrologic and geomorphic settings across North America. Spatial patterns in lake variables driven by landscape position were surprisingly common across lake districts and across a wide range of variables. On the other hand, temporal patterns of lake variables, quantified using synchrony, the degree to which pairs of lakes exhibit similar dynamics through
\end{abstract}

\section{INTRODUCTION}

Spatial variation within and among lakes has been recognized as playing an important role in structur-

Received 2 February 1999; accepted 14 June 1999

*Corresponding author's current address: Department of Fisheries and Wildlife, 10A Natural Resources Building, Michigan State University, East Lansing, Michigan 48824, USA.

e-mail: soranno@pilot.msu.edu time, related to landscape position only for lake chains with lake water residence times that spanned a wide range and were generally long (close to or greater than 1 year). Highest synchrony of lakes within a lake chain occurred when lakes had short water residence times. Our results from both the spatial and temporal analyses suggest that certain features of the landscape position concept are robust enough to span a wide range of seemingly disparate lake types. The strong spatial patterns observed in this analysis, and some unexplained patterns, suggest the need to further study these scales and to continue to view lake ecosystems spatially, longitudinally, and broadly across the landscape.

Key words: landscape position; lake variability; lake districts; synchrony; coherence; north temperate lakes; lake chains; lake order; lake number; water residence time. ing lake ecosystems at a variety of scales. The natural boundary of the lake shoreline has long focused the attention of limnologists on the lake as the unit of study (Forbes 1887). Understanding spatial patterns within individual lakes occupied early limnologists since they first lowered thermometers and water samplers into deep stratified lakes (Forel 1892; Birge and Juday 1911). The observed vertical gradients in light, temperature, oxygen, and nutrients were viewed as major drivers of ecological 
processes. A more systemwide view evolved with the recognition of the key role played by interactions between lakes and their watersheds and airsheds (Likens 1984; Likens 1985; Schindler and others 1990; Kling and others 1991). Lakes were viewed as an integral component of the larger aquatic-terrestrial ecosystem with catchment characteristics, such as geology, land use/cover, and topography used to explain interlake variation in the chemical and trophic status of lakes (Dillon and Kirchner 1975; Omernik 1976; Driscoll and van Dreason 1992; Gibson and others 1995).

Limnologists now recognize that interlake variability is driven by factors acting at both regional (for example, climate, atmospheric deposition, and regional landscape characteristics) and local scales (for example, lake morphometry, foodwebs, land use/ cover, geomorphic setting, and hydrology). However, there is still a significant amount of unexplained variation among lakes of similar features and occupying seemingly identical physical settings. General organizing principles that explain interactions among lakes within a region in a spatially explicit manner may help explain some of this variation. Until recently, no such principles have existed for lakes.

In contrast to lakes, streams have been viewed spatially within a landscape for some time. The longitudinal view of streams from headwaters to river mouth has allowed stream ecologists to use geomorphic and hydrologic gradients as a fundamental physical template for streams at large spatial scales. The River Continuum Concept (Vannote and others 1980; Minshall and others 1985) and more recent constructs have postulated differences in land-water linkages along important spatial gradients (Frissell and others 1986; Junk and others 1989; Wiley and others 1990). Streams have been viewed as open systems, strongly linked to surrounding landscapes through material exchange, with explicit linkages between up- and downstream segments (Hynes 1975; Ward and Stanford 1983; Frissell and others 1986; Fisher and Grimm 1991).

Recently, lake ecologists have begun to recognize spatial patterning among lakes at larger scales by using the idea of landscape position (Kratz and others 1997; Magnuson and others forthcoming; Riera and others forthcoming; Webster and others forthcoming). The landscape position concept was developed in northern Wisconsin, a region where groundwater flowpaths generate strong spatial patterns in lakes across the landscape (Kratz and others 1997). In fact, distinctions between high- and lowgradient lakes were first identified in the early 1900s by E.A. Birge and C. Juday, who contrasted features of seepage and drainage lakes, defined by absence or presence, respectively, of surface water inlets and outlets (Juday and Meloche 1943). Neighboring lakes sharing a common climate, geologic setting, and regional species pool differ systematically in many of their features as a function of their hydrology and geomorphology (Winter 1977; Eilers and others 1983; Rochelle and others 1989; Kratz and others 1997; Riera and others forthcoming; Webster and others forthcoming; Magnuson and others forthcoming). Position of lakes along gradients such as these is defined in part by the strength of the interaction between lakes and the landscape. Higher inputs of landscape-derived materials occur in lakes lower in the landscape because water entering these lower lakes has been in contact with soil longer (Drever 1982).

Here, we explore this landscape position concept for lakes by analyzing patterns along lake chains (lakes in a series connected through surface or groundwater flow). We examine lakes in a series as a simple quantification of landscape position to try to capture the spatially explicit linkages between lakes and the landscape. We ask the following two questions: (a) Are there predictable spatial patterns in chemical, algal, and water clarity variables within lake chains?; and (b) Do spatial patterns of variables within a lake chain influence the temporal dynamics of lakes? To answer the above questions, we examined spatial patterns of lake variables along nine different lake chains. To test the generality of the concept, we considered lake chains from a wide range of landscape types (alpine, prairie, tundra, and glacial plains) and hydrologic settings (groundwater-dominated seepage lakes, surface drained lakes, and large main stem and tributary reservoirs).

\section{General Predictions}

Predicting and understanding lake concentrations of a wide range of chemical variables has been the subject of much research over the past 30 y (see Reckhow and Chapra 1983). In particular, the steady state mass-balance model has been used successfully to understand dynamics of nitrogen (Molot and Dillon 1993; Windolf and others 1996), dissolved organic carbon (Dillon and Molot 1997; Schindler and others 1997), and most notably phosphorus (Vollenweider 1969; Reckhow and Chapra 1983; Dillon and Molot 1996). The model states that the steady state standing stock of a constituent (over a given time period) will equal total loadings plus or minus transports, plus or minus reactions (Reckhow and Chapra 1983). Unfortunately, this model typically has been applied only to individual lakes or groups of unconnected lakes. We are interested in 
how it can be applied to lakes in a landscape context. The mass-balance model provides the mechanisms for determining how landscape position can influence the concentrations of important lake constituents along a landscape gradient. Because building a complete mass-balance model for multiple lakes along nine different lake chains is not possible in our study due to data limitations, we are not able to fully answer our questions by using the mass-balance model. However, to make predictions about how landscape position influences lake solute concentrations, we can examine patterns and infer likely mechanisms based on the following assumptions: (a) loading increases as the watershed to lake area ratio (WS:LK) increases; (b) transport and retention within a lake depends on water residence time (WRT); and (c) patterns for individual variables depend on retention strength and reactivity.

We are interested in whether concentrations of lake constituents vary predictably down lake chains. For example, higher solute concentrations in lakes further down the lake chain mean that either more solutes are entering the lake, less solutes are leaving the lake, or less solutes are being transformed within the lake. We assume that landscape position affects only the first case. We make the following predictions based on the above assumptions. First, for relatively nonreactive solutes (for example, those subject to weathering processes, such as calcium and alkalinity), biological or chemical reactions affecting them in the lake itself will be minor, and thus inputs should equal outputs. However, because we expect weathering to increase down the lake chain due to increased contact time of incoming water with soil, total loading, and standing stocks of these variables should increase down the lake chain. And, because these nonreactive solutes will undergo little change once in the lake, WRT should have no effect on lake concentrations. For more reactive solutes or particulates (such as other dissolved ions, dissolved and total nutrients, and algal variables), reactions within the lake are most likely a large term in the equation, and so lake concentrations should be influenced by WRT. WRT will influence the length of time that these reactions have to proceed, and that may lead to either increases or decreases in constituents down the lake chain depending on the variable. For example, it has been shown that lakes often retain a significant portion of the phosphorus that is transported to them (Reckhow and Chapra 1983). Thus, we expect that lakes will act as retention basins and nutrient transport down the chain will decrease, especially in lakes with long WRT.

Landscape position also may influence the temporal dynamics of lake constituents. We expect that if large spatial gradients exist in solute concentrations along the lake chain, then interannual dynamics among lakes may be different, and lakes that are closer together along the chain may be more similar than lakes farther apart. In lake chains where no or few spatial gradients exist in lake concentrations, similar drivers acting on similar time scales should override spatial drivers, and lakes should vary synchronously through time.

We expect that specific landscape characteristics of each lake district will determine the presence and the strength of the above spatial and temporal patterns along lakes chains. For example, the geologic setting, and in particular the characteristics of the soil and the presence of glacial till, will determine the rate of weathering in the surrounding landscape and the availability of materials to be transported from land to water. Also, the hydrologic setting of the chain will determine the WRT. In general, the slower flowpaths of groundwater-fed lakes cause them to have longer WRT than surface drainage lakes of similar size and volume. Among surface drainage lakes, the shortest water residence times typically are observed in reservoir chains.

In summary, we expect that for nonreactive variables all lake chains regardless of WRT will show increasing concentrations down the lake chain. For reactive variables, concentrations should either increase or decrease down the chain depending on the variable and on lake-specific reaction rates. Thus the predictability of changes in reactive variables across space should not be generalizable, but patterns of behavior of specific variables among different lake chains may emerge. Our goal here is not to exhaustively explain patterns along individual lake chains, but rather, to identify general patterns to arrive at a more synthetic understanding of lake variation along spatial gradients within a wide range of lake districts. We test the general utility of the landscape position concept by considering lake chains in districts of diverse hydrologic and geomorphic settings. In short, we address when and where the spatial arrangement of lakes within a landscape matters to lake functioning.

\section{LAKE Districts}

Nine lake chains from seven lake districts in North America were analyzed (Figure 1; see Table 1 for references). We analyzed data from lake chains in two lake districts that are part of the North Temperate Lakes Long Term Ecological Research (LTER) program, one in the Northern Highlands District of northern Wisconsin (WIS-N), and one near Madison in southern Wisconsin (WIS-S); the Arctic LTER 


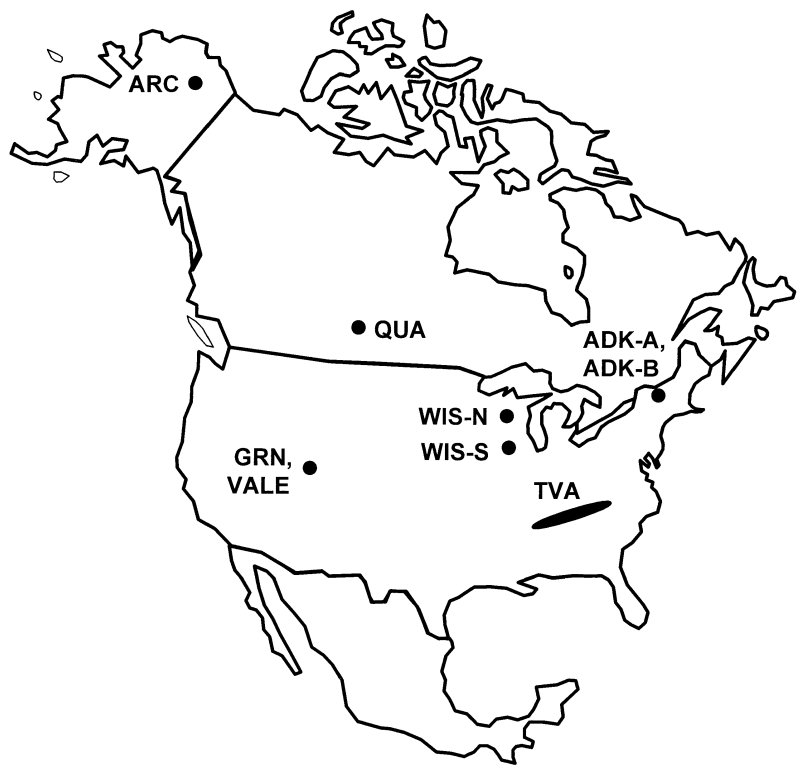

Figure 1. Location of the nine lake chains in North America: the LTER lake chain in Northern Highlands District of northern Wisconsin (WIS-N), and of southern Wisconsin (WIS-S); the Arctic Lakes LTER lake chain (ARC); two lake chains in the Adirondack Region lake district (ADK-A and ADK-B); two lake chains in the Rocky Mountain Front Range region of Colorado, the Green Lakes valley chain (GRN), and the Loch Vale watershed lake chain (VALE); a single lake chain in the Qu'Appelle Valley River Basin in Saskatchewan, Canada (QUA); and a single lake chain of a tributary and mainstem reservoir series of the Tennessee River (TVA).

lake chain in Alaska (ARC); two lake chains of the North Branch of the Moose River in the Adirondack Region Lake District (ADK-A and ADK-B); two lake chains in the Rocky Mountain Front Range region of Colorado [Green Lakes Valley chain (GRN) and Loch Vale Watershed lake chain (VALE)]; a single prairie lake chain in the Qu'Appelle Valley River Basin in Saskatchewan that includes one headwater reservoir and three natural lakes (QUA); and a lake chain of the tributary and main-stem reservoir series of the Tennessee River (TVA). In addition to the TVA lake chain, dams are present on the two lower lakes in the GRN chain and in the second lake in the QUA chain.

The lake districts represent a wide range of geologic conditions, land use/cover, and hydrology (Table 1). Geologic settings range from glaciated regions with thick glacial till over sedimentary deposits to exposed Precambrian granite with little or no till. Land cover in two districts is predominantly second growth forest (WIS-N, ADK-A, and ADK-B), the Rocky Mountain district is a combination of forest and alpine habitats (GRN and VALE), one district is arctic tundra with only an approximately $0.5-\mathrm{m}$ thaw depth in the summer months (ARC), and in three districts land use is dominated by agriculture with some urban components (WIS-S, QUA, and TVA). Hydrology of lake chains is equally diverse, including groundwater-dominated lakes (WIS-N), surface-water-dominated chains of all natural lakes (WIS-S, ARC, ADK-A, ADK-B, GRN, and VALE), a combination of natural lakes and reservoirs (QUA), and all reservoirs (TVA). The lake districts with reservoirs appear to be relatively similar hydrologically to the other chains given that WRT in the reservoirs are well within the range of WRTs found in the other chains (see Figure 2).

Although all lake chains have direct linear connections through either surface streams or the regional groundwater flow system, midchain lakes were not sampled in some chains. In GRN, lake 3 (of a total of five) was not included, but when this lake was systematically sampled for 1 y in 1985, its characteristics were found to be intermediate between the adjacent lakes in the series (N. Caine, unpublished data). In the QUA chain, only lakes 1, 2, 7, and 8 were sampled. The number of lakes per chain ranges from 3 (ADK-B and RLCH) to 13 (TVA; Table 1). The two Adirondack lake chains share the same final lake in the chain. The total distance from headwater lake to the last downstream lake ranges from $2 \mathrm{~km}$ to more than $1000 \mathrm{~km}$.

\section{METHODS}

\section{Lake Database}

Lake data were assembled from either published long-term studies of the lakes (WIS-N, ARC, ADK-A, ADK-B, RGRN, VALE, and QUA) or a combination of unpublished and published data (WIS-S and TVA; see Table 1 for citations). Data records generally extend from the early 1980s through the mid-1990s except for ARC, QUA, and TVA, which were sampled from 1991 to 1997, 1994 to 1997, and 1990 to 1994, respectively (Table 1). Analyses were based on annual open-water (nonwinter in the case of TVA) epilimnetic means, except for chlorophyll $a$ in WIS-N for which we used the June through August mean. Samples were collected every 2-4 weeks for all variables, except in WIS-N and WIS-S where cations were sampled quarterly (excluding winter). Samples were collected midlake from all lakes except in ADK-A, ADK-B, GRN, and VALE where outlet samples were collected.

Variables were divided into three main groups: (a) weathering products (conductivity, pH, alkalinity, and $\mathrm{Ca}$ ); (b) dissolved nutrients and other major ions $\left(\mathrm{SO}_{4}, \mathrm{NO}_{3}, \mathrm{NH}_{4}\right.$, and $\mathrm{SiO}_{2}$, measured as dis- 
Table 1. Characteristics of Lake Districts and Study References

\begin{tabular}{|c|c|c|c|c|c|c|c|c|c|}
\hline Lake District & $\begin{array}{l}\text { State or } \\
\text { Province }\end{array}$ & $\begin{array}{l}\text { Lakes in } \\
\text { Lake Chain }^{a}\end{array}$ & Hydrology & Geology & $\begin{array}{l}\text { Land Use or } \\
\text { Land Cover }\end{array}$ & $\begin{array}{l}\text { Elevation } \\
\text { Change }^{b} \\
(\mathrm{~m})\end{array}$ & $\begin{array}{l}\text { Chain } \\
\text { Length } \\
\text { (distance, } \\
\mathrm{km})^{c}\end{array}$ & $\begin{array}{l}\text { Chain } \\
\text { Length } \\
\text { (no. } \\
\text { lakes) }\end{array}$ & Years \\
\hline $\begin{array}{l}\text { Northern Highland } \\
\text { Lakes } \\
\text { District-LTER }{ }^{d} \\
\text { (WIS-N) }\end{array}$ & Wisconsin & $\begin{array}{l}\text { Crystal, Big Muskellunge, } \\
\text { Sparkling, Allequash, } \\
\text { Trout }\end{array}$ & Groundwater & $\begin{array}{l}\text { Sandy outwash plains of Laurentian } \\
\text { Shield sand or coarse till } \\
\sim 40 \text { m of noncalcareous sandy tills and } \\
\text { outwash }\end{array}$ & Forested & $\sim 9$ & $\sim 5$ & 5 & $\begin{array}{r}1982- \\
1995\end{array}$ \\
\hline $\begin{array}{l}\text { Southern Wisconsin } \\
\text { Lakes }^{e} \text { (WIS-S) }\end{array}$ & Wisconsin & $\begin{array}{l}\text { Mendota, Monona, } \\
\text { Waubesa, Kegonsa }\end{array}$ & Surface water & $\begin{array}{l}\text { Unconsolidated glacial deposits } \\
\text { underlain by sedimentary rocks } \\
\sim 50-100 \text { m glacial till }\end{array}$ & $\begin{array}{l}\text { Agricultural and } \\
\text { urban }\end{array}$ & 2 & $\sim 18$ & 4 & $\begin{array}{r}1982- \\
1994\end{array}$ \\
\hline $\operatorname{Arctic}-\mathrm{LTER}^{f}(\mathrm{ARC})$ & Alaska & $\begin{array}{l}\text { I-1, I-3, I-4, I-5, I-6, I-7, } \\
\text { Toolik Lake }\end{array}$ & Surface water & $\begin{array}{l}\text { Glacial outwash surrounded by glacial } \\
\text { surfaces of } \sim 10,000 \text { to } 100,000 \text { y in } \\
\text { age }\end{array}$ & $\begin{array}{l}\text { Arctic tundra (cov- } \\
\text { ered in } 0.3-1.2 \mathrm{~m} \\
\text { of peat). Thaw } \\
\text { depth } \sim 0.5 \mathrm{~m} \text { in } \\
\text { summer }\end{array}$ & 66 & $\sim 8.5$ & 7 & $\begin{array}{r}1991- \\
1997\end{array}$ \\
\hline $\begin{array}{l}\text { Adirondacks Region } \\
\text { lakes }^{g} \text { (ADK-A, } \\
\text { ADK-B) }\end{array}$ & New York & $\begin{array}{l}\text { A: Constable, Big Moose, } \\
\text { Dart's, Rondaxe } \\
\text { B: Cascade, Moss, Rondaxe }\end{array}$ & Surface water & $\begin{array}{l}\text { Granitic gneiss with metasedimentary } \\
\text { rock and heterogeneous soils } \\
<3 \mathrm{~m} \text { thin till }\end{array}$ & Forested & $\begin{array}{l}\text { A: } 57 \\
\text { B: } 29\end{array}$ & $\begin{array}{r}\sim 11 \\
\sim 8\end{array}$ & $\begin{array}{l}\text { A: } 4 \\
\text { B: } 3\end{array}$ & $\begin{array}{r}1983- \\
1993\end{array}$ \\
\hline $\begin{array}{l}\text { Rocky Mountain } \\
\text { lakes }^{h}(\text { GRN, } \\
\text { VALE) }\end{array}$ & Colorado & $\begin{array}{l}\text { GRN: Green Lake 5, Green } \\
\text { Lake 4, Green Lake 2, } \\
\text { Lake Albion } \\
\text { VALE: Sky Pond, Glass Lake, } \\
\text { The Loch }\end{array}$ & Surface water & $\begin{array}{l}\text { Precambrian granite, schist, and gneiss } \\
\text { None or thin soils }\end{array}$ & $\begin{array}{l}\text { GRN: subalpine } \\
\text { VALE: alpine }\end{array}$ & $\begin{array}{l}\text { GRN: } 275 \\
\text { VALE: } 274\end{array}$ & $\begin{array}{l}\text { GRN: } \sim 5 \\
\text { VALE: } \sim 2\end{array}$ & $\begin{array}{l}\text { GRN: } 4 \\
\text { VALE: } 3\end{array}$ & $\begin{array}{r}1984- \\
1996\end{array}$ \\
\hline $\begin{array}{l}\text { Qu'Appelle Valley } \\
\text { reservoirs and } \\
\text { lakes }^{i} \text { (QUA) }\end{array}$ & Saskatchewan & $\begin{array}{l}\text { Diefenbaker, Buffalo Pound, } \\
\text { Katepwa, Crooked Lake }\end{array}$ & $\begin{array}{l}\text { Surface water } \\
\text { lakes and } \\
\text { reservoirs }\end{array}$ & Northern great plains prairies. & Agricultural & 100 & $\sim 315$ & 4 & $\begin{array}{r}1994- \\
1997\end{array}$ \\
\hline $\begin{array}{l}\text { Tennessee River } \\
\text { Valley Authority } \\
\text { reservoirs' (TVA) }\end{array}$ & $\begin{array}{l}\text { Tennessee, Alabama, } \\
\text { and } \\
\text { Kentucky }\end{array}$ & $\begin{array}{l}\text { Upper tributary: Wautauga, } \\
\text { Boone, Ft. Patrick Henry, } \\
\text { Cherokee } \\
\text { Middle mainstem: Fort } \\
\text { Loudon, Watts Bar, } \\
\text { Chickamauga, Nickajack } \\
\text { Lower mainstem: } \\
\text { Guntersville, Wheeler, } \\
\text { Wilson, Pickwick } \\
\text { Landing, Kentucky }\end{array}$ & Reservoirs & $\begin{array}{l}\text { Upper: Ridge and valley province, } \\
\text { underlain by folded and faulted } \\
\text { paleozoic limestones, shale, and } \\
\text { sanstone (thin soils, no till) } \\
\text { Middle: Cumberland section of } \\
\text { Appalachian Plateau, underlain by } \\
\text { Mississippian limestones and } \\
\text { sandstone (thin soils, no till) } \\
\text { Lower: interior Low Province underlain } \\
\text { by Mississippiam, Ordovician, and } \\
\text { Devonian limestones } \\
\text { Soils weathered limestones }\end{array}$ & $\begin{array}{l}\text { Agricultural with } \\
\text { some forested } \\
\text { areas }\end{array}$ & 411 & $\sim 1000$ & 13 & $\begin{array}{r}1990- \\
1994\end{array}$ \\
\hline \multicolumn{10}{|c|}{ 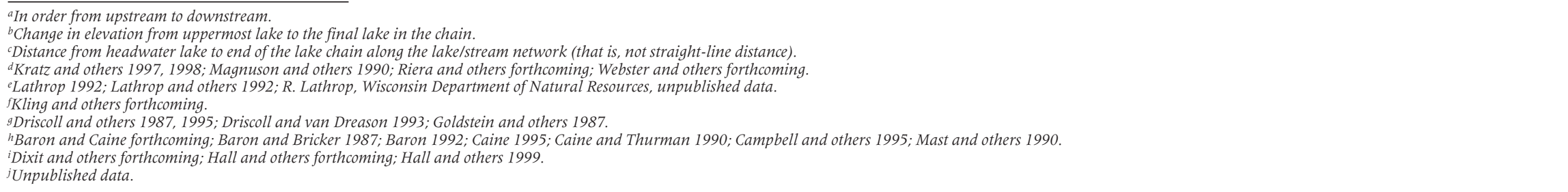 } \\
\hline
\end{tabular}




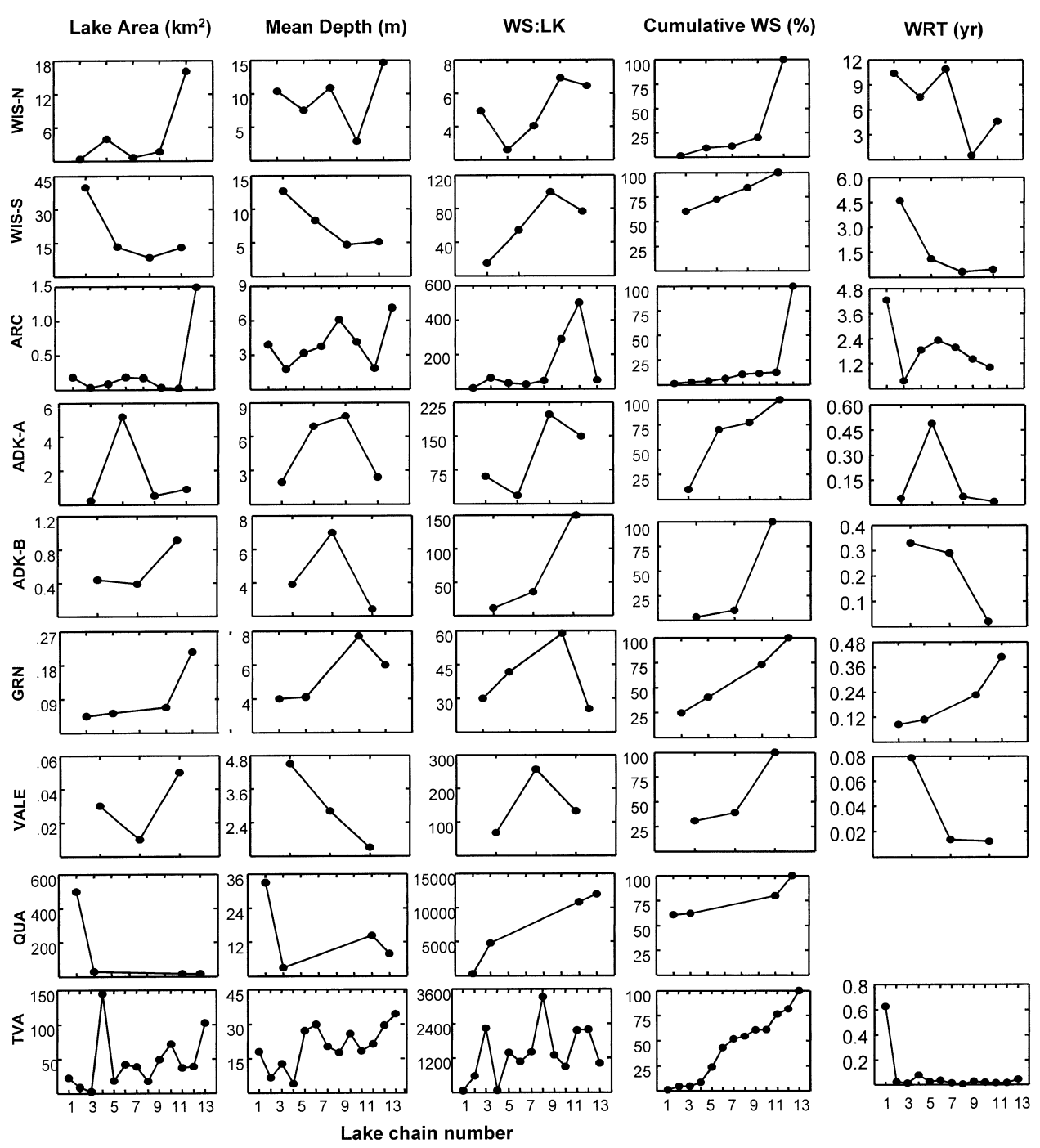

Figure 2. Individual characteristics for lake and watershed morphometry and water residence time. WS:LK is the watershed area to lake area ratio (unitless); cumulative WS is the cumulative watershed area (\%) of lakes along each lake chain (thus lower lakes in the chain include watershed areas of upper lakes); and WRT is water residence time (yr).

solved reactive silica); and (c) total nutrients and water clarity (total $\mathrm{P}$, total $\mathrm{N}$, chlorophyll $a$, and Secchi depth). Specific methods and sampling details are found in the data references listed in Table 1.

\section{Analysis}

Each lake in a chain was assigned a sequential number starting with 1 for the lake highest in the landscape (headwater lake). Spatial patterns along each lake chain were then examined using box plots of the average of annual solute concentrations versus lake chain number. These box plots show the range of annual values observed for each lake throughout the period of record.

Temporal patterns in lake dynamics within individual lake chains were assessed by calculating synchrony. Synchrony, also called temporal coherence, is a measure of the similarity in interannual concentrations between a lake pair (Magnuson and others 1990; Kratz and others 1998; Baines and others 1999). Synchrony for each variable was calculated as the Pearson product-moment correlation coefficient $(r)$ between time series of annual data for every lake pair within a chain. QUA and TVA chains, which only had $4 \mathrm{y}$ of data, were excluded from the analysis.

We first examined synchrony within individual lake chains to examine the importance of landscape position and to determine if nearby pairs were more synchronous than spatially separated pairs. We regressed lake chain number difference (the absolute difference between lake chain number for the lake pair) against lake pair synchrony for each lake chain. We then examined average synchrony among lake chains. For each variable group, we regressed the average synchrony for each variable within a lake chain versus the median WRT and WS:LK for each lake chain. Only weathering and dissolved nutrient/ion groups were used for this analysis 
because data for total $\mathrm{P}$, total $\mathrm{N}$, chlorophyll $a$, and Secchi depth were missing from many sites.

\section{RESULTS}

\section{Lake Chain Spatial Patterns}

To more fully understand the landscape position of lakes, we needed to first identify whether individual lake morphometry and WRT change predictably with lake number. We found few consistent patterns in individual lake characteristics along lake chains (Figure 2). There was a weak tendency in some lake chains for mean depth to decrease and lake area to increase with lake chain number. However, the strongest pattern observed was an increase in WS:LK, which supports our assumption that loading increases down the lake chain. We also saw a general decrease in WRT down the lake chain, although these trends were not present in all lake chains. In chains where WRT did not follow this trend, the absolute range in WRT among lakes in the chain was very small (ADK-A, ADK-B, GRN, and VALE). Cumulative watershed area obviously increased along each lake chain because lake chain watersheds are hierarchical and lower lake watersheds include basins from upper lakes. However, watershed area shows three patterns of accumulation (Figure 2). In the first case, there is a gradual, proportional increase in cumulative watershed area along the lake chain (ADK-A, GRN, and TVA). In the second case, the watershed of the last lake in the chain is disproportionally large relative to the lower lakes (WIS-N, ADK-B, and VALE). In the third case, the watershed of the first lake in the chain is disproportionally large relative to the lower lakes (WIS-S and QUA). These patterns and other lack of patterns in morphometry are necessary to interpret the role of lake number in influencing lake variables.

Weathering variables, alkalinity, conductivity, and calcium generally increased along almost all lake chains, consistent with our expectation that loading from the landscape would be higher in lakes lower in lake chains (Figure 3). However, these patterns were less developed where lakes were situated in calcium-rich tills (WIS-S) or areas with high local heterogeneity in geologic substratum (ADK-A and ADK-B; Driscoll and van Dreason 1993).

Although silica is a dissolved nutrient subject to biological uptake and driven by in-lake processes, spatial patterns were more suggestive of a nonreactive weathering variable than a reactive element (Figure 4). In three lake chains, WIS-N, WIS-S, and ADK-A, dissolved silica concentration increased with increasing lake chain number, and in ADK-B, the only chain where other weathering variables actually decreased due to geologic heterogeneity, silica also decreased. In WIS-S, silica was higher in the lower two lakes, which are shallow and likely subject to recycling of biogenic silica from the sediments.

The remaining dissolved nutrients and reactive compounds showed fewer patterns with landscape position and appeared to be sensitive to lake chainspecific or local conditions affecting internal processing rates. However, there were a few commonalities among lake chains (Figure 4). For example, because sulfate is of both atmospheric and geologic origin, we expected strong spatial patterns only where sulfur-bearing minerals are present in the surrounding landscape. Sulfate does slightly increase with lake chain number in two districts that do have sulfur-bearing minerals (WIS-S and GRN). Spatial patterns in nitrate on the other hand were more variable and not predictable from landscape position alone and are not explainable with our data here. For example, patterns observed in WIS-S and QUA lake chains for nitrate may have been influenced by a combination of lake morphometry and land-use loading rates. A decrease in nitrate occurs in both chains after the first lake. In both lake chains, the first lake's watershed is not only large (making up approximately $60 \%$ of the total chain watershed area; Figure 2) but is dominated by agricultural land use, which can increase nitrate inputs. In contrast, the lower lakes' watersheds add little additional watershed area and, in the case of WIS-S, have less proportional areas under agricultural production.

In contrast to our expectations based on massbalance assumptions, concentrations of total nutrients [TP and TN (not shown)] and measures of algal biomass (chlorophyll) increased with increasing lake number in two of the surface-drained lake chains but not the groundwater-dominated lake chain (Figure 5). Patterns for surface-drained chains TVA and ARC showed complex patterns that are not explainable given our data. Secchi depth showed the most consistent pattern, with decreases along all lake chains except ARC. As a measure of water clarity, Secchi depth is the net result of chlorophyll concentration, colored dissolved organic carbon (DOC), and suspended sediments-all of which appear to be related to lake number.

\section{Lake Chain Temporal Dynamics}

Across all lake chains, weathering variables were the most synchronous among lake pairs within a chain, followed by the dissolved nutrients and ions, 
$\operatorname{ALK}\left(\mu e q L^{-1}\right)$
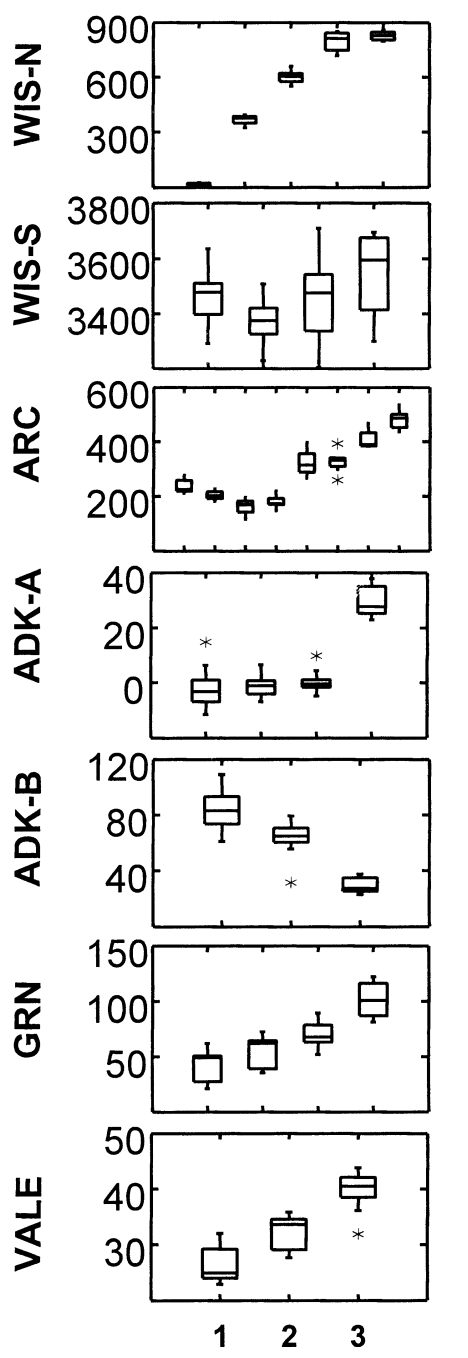

$\stackrel{5}{0}$

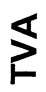

COND $\left(\mu \mathrm{S} \mathrm{cm}^{-1}\right)$
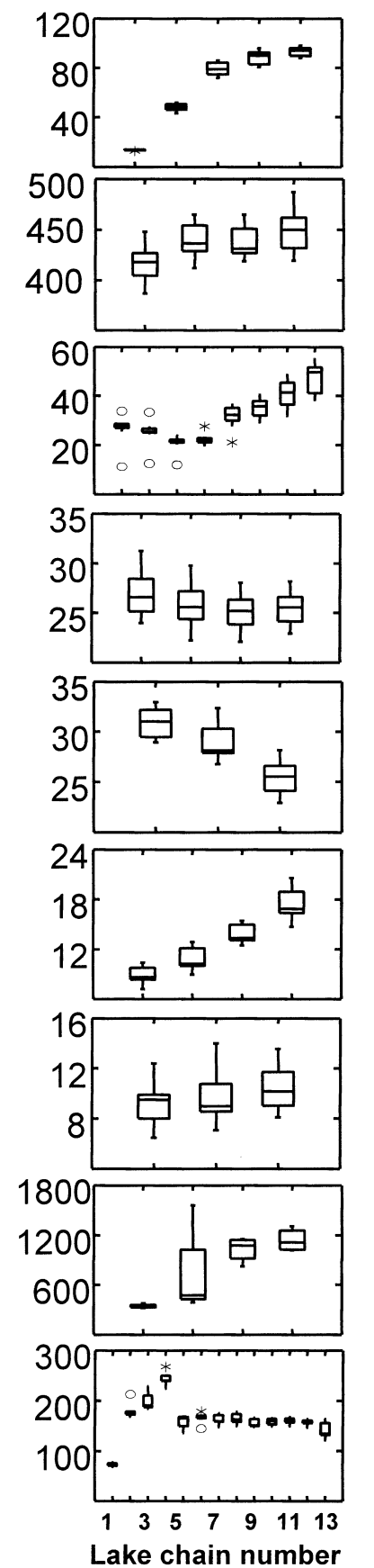

and then total nutrients and algal variables (Table 2, Total row). This pattern fits well with results from other studies of synchrony (Magnuson and others 1990; Kratz and others 1998; Webster and others forthcoming) that have shown nonreactive ions to be the most synchronous and biological variables to be the least synchronous.

At the scale of individual lake chains, our expectations that lakes with strong spatial gradients should have low synchrony was not proven. Landscape

\section{$\mathrm{Ca}\left(\mu \mathrm{eq} \mathrm{L} \mathrm{L}^{-1}\right)$}
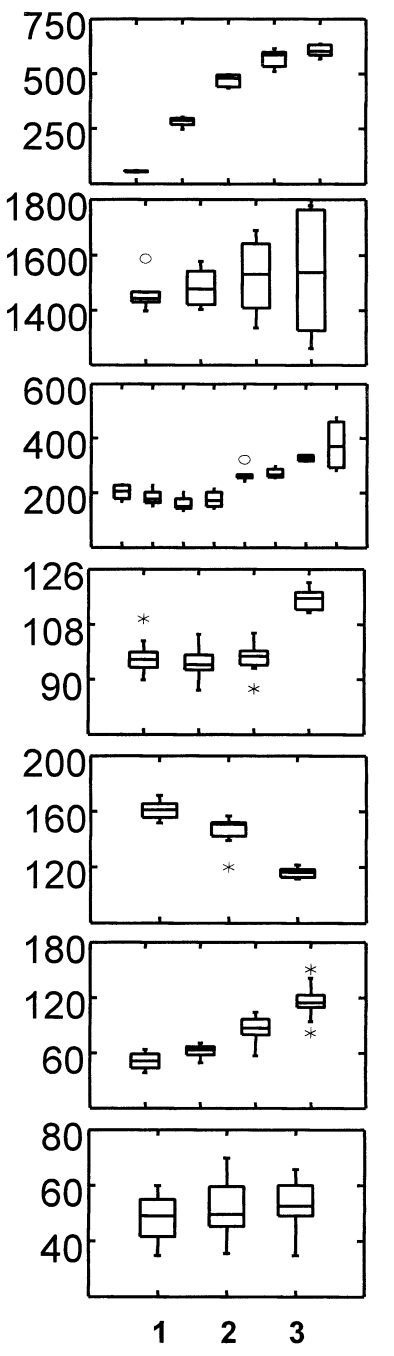

Figure 3. Box plots of annual averages of three of the variables used as a measure of weathering (ALK, alkalinity; COND, conductivity;

$\mathrm{Ca}$, calcium concentration) for each lake versus lake chain number. Note that for the GRN and QUA lake chains, some intermediate lakes were not sampled so that the maximum lake chain number is larger than the maximum number of lakes plotted (see text and Figure 2). position proved to be important in determining synchrony between lake pairs only for some variables related to weathering (Table 3). Here, regressions of lake pair synchrony against the difference in their lake chain number (suggesting that lakes closer in the chain will be more temporally similar) were significant for only three lake chains, WIS-N, WIS-S, and ARC. These three lake chains have the longest average WRT, close to or exceeding $1 \mathrm{y}$ (Figure 2). In addition, all of these lake chains had 


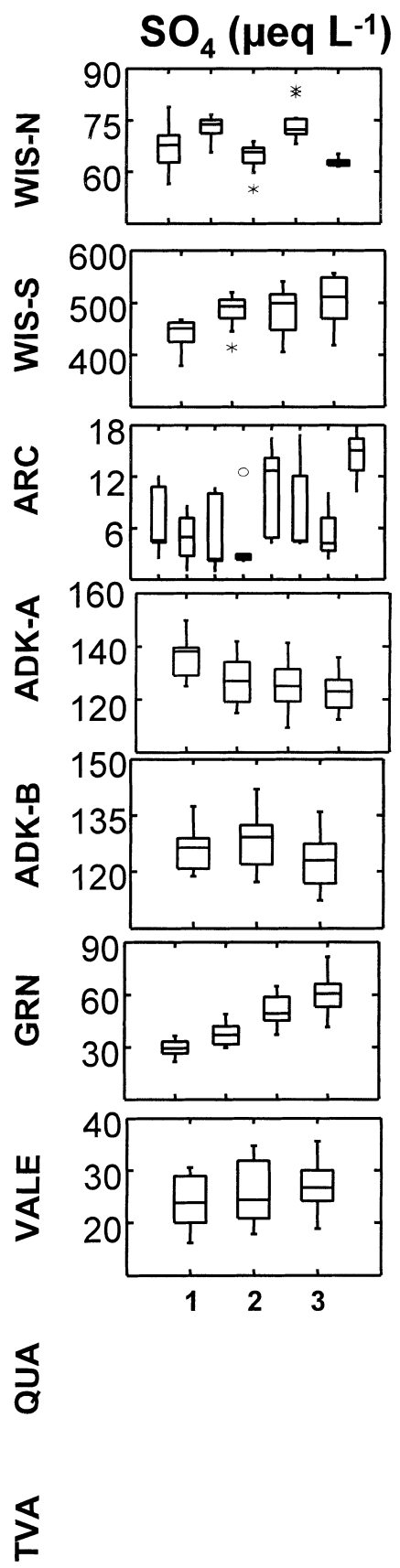

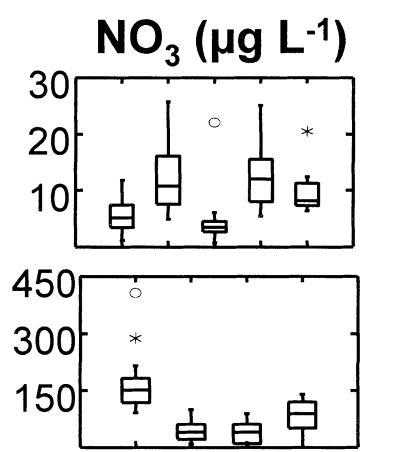

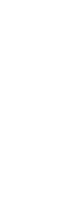
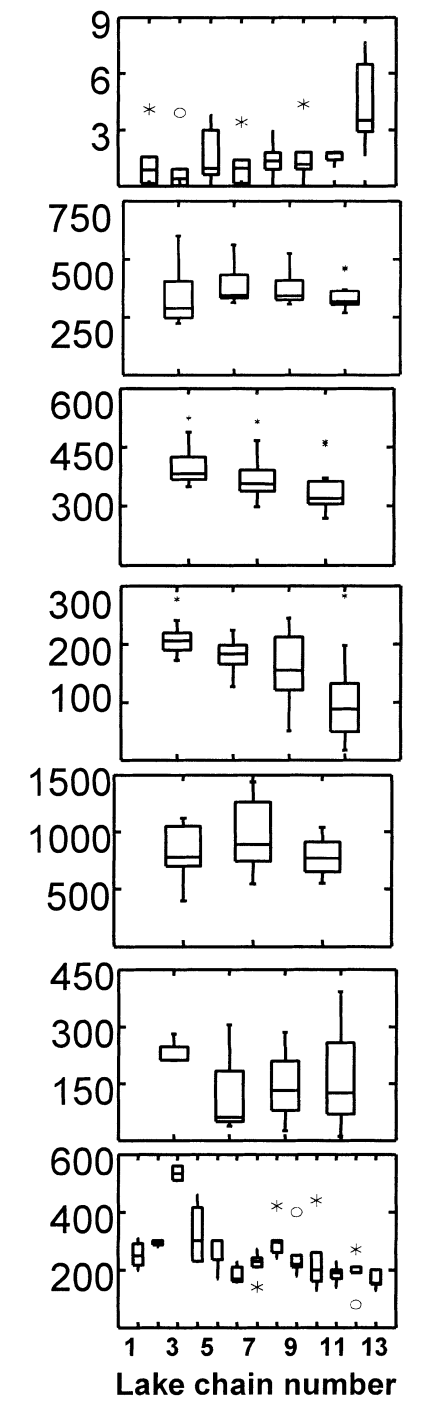

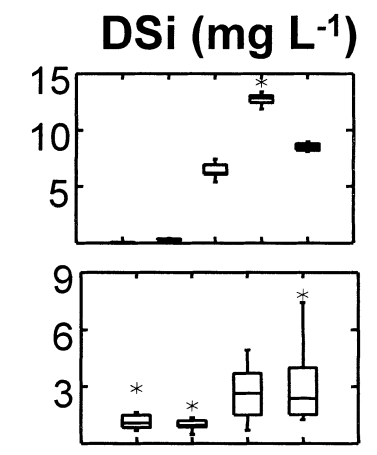

Figure 4. Box plots of annual averages of three dissolved nutrient and ion variables $\left(\mathrm{SO}_{4}\right.$, sulfate; $\mathrm{NO}_{3}-\mathrm{N}$, nitrate; $\mathrm{DSi}$, dissolved silica) for each lake chain versus lake chain number. Note that for the GRN and QUA lake chains, some intermediate lakes were not sampled so that the maximum lake chain number is larger than the maximum number of lakes plotted (see text and Figure 2).

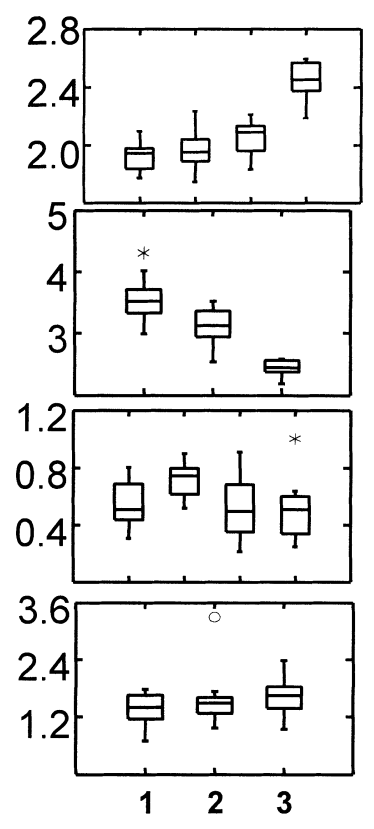

the largest range of WRT among lakes within a chain. Whether these large differences in WRT among the lake chains, or some other feature of landscape position cause the differences in synchrony at these sites remains to be seen. In the remaining sites, however, the high average synchrony between lake pairs (Table 2) indicates that synchrony across these lake chains was unrelated to landscape position.

At the scale of multiple lake chains, if we compare average lake chain synchrony (Table 2, Total column), there appears to be large differences among lake chains. To examine whether hydrologic characteristics of the lake chains influenced their temporal patterns, we regressed synchrony for each variable within the group (except total nutrients and algae) against the median log-transformed WRT and the median WS:LK (Figure 6) for each lake chain. We 

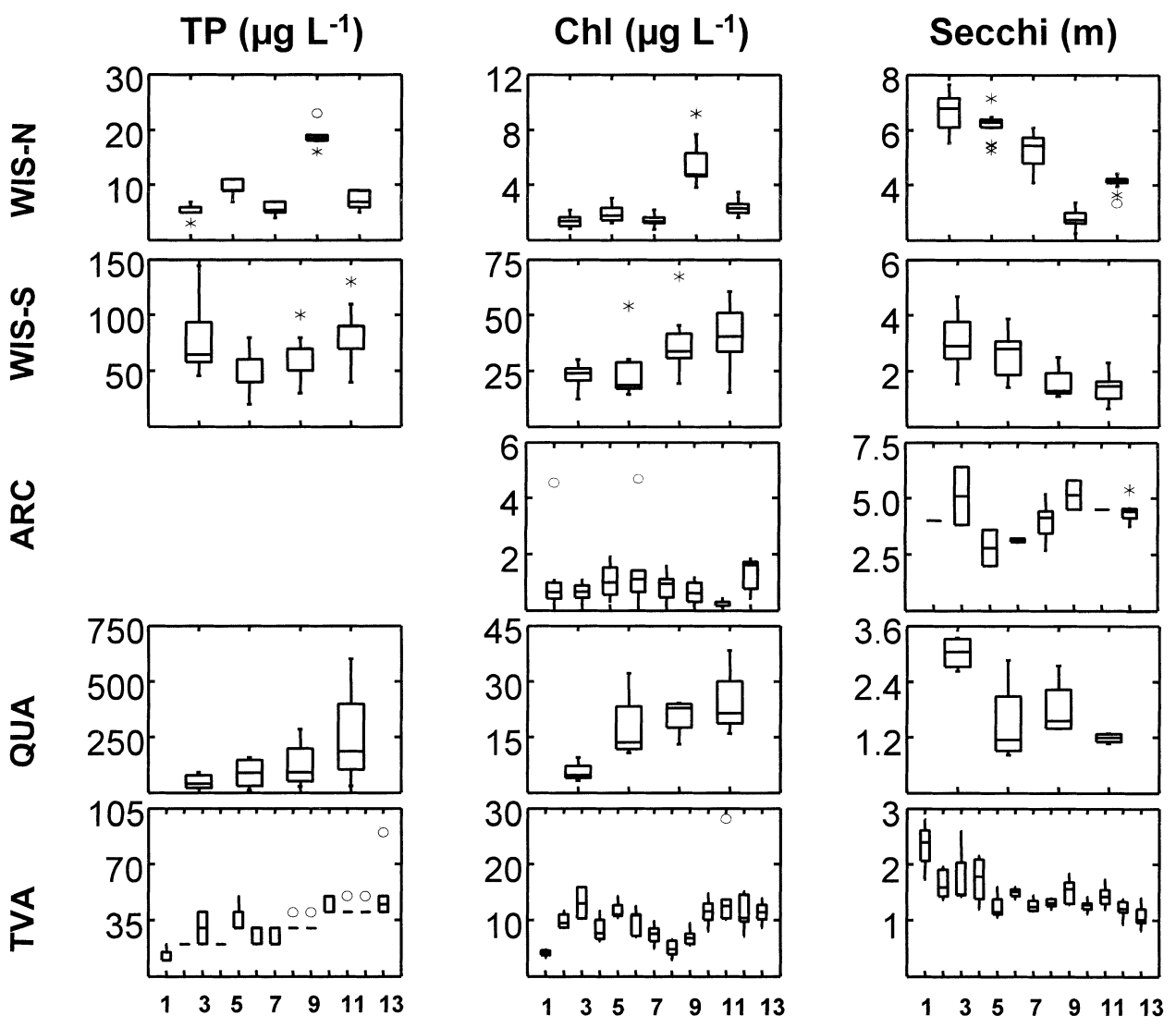

Figure 5. Box plots of annual averages for total nutrients and water clarity variables [total phosphorus concentration (TP), chlorophyll a concentration (Chl), and Secchi depth]. Note that for the QUA lake chain, some intermediate lakes were not sampled so that the maximum lake chain number is larger than the maximum number of lakes plotted (see text and Figure 2). Data are not available for ADK-A, ADK-B, GRN, and VALE.

Lake chain number

Table 2. Average Synchrony $(r)$ Values for Each Lake Chain

\begin{tabular}{|c|c|c|c|c|c|c|c|c|c|c|c|c|c|}
\hline \multirow[b]{2}{*}{ District } & \multicolumn{4}{|c|}{ Weathering Variables } & \multicolumn{4}{|c|}{ Dissolved Nutrients and Ions } & \multicolumn{4}{|c|}{ Total Nutrients and Water Clarity } & \multirow[b]{2}{*}{ Total } \\
\hline & Alk & Cond & $\mathrm{PH}$ & $\mathrm{Ca}$ & $\mathrm{SO}_{4}$ & $\mathrm{NO}_{3}-\mathrm{N}$ & $\mathrm{NH}_{4}-\mathrm{N}$ & DSi & TP & $\mathrm{TN}$ & Chl & Secc & \\
\hline WIS-N & 0.835 & 0.685 & 0.805 & 0.811 & 0.185 & 0.077 & 0.585 & 0.090 & 0.139 & 0.573 & 0.469 & 0.227 & 0.457 \\
\hline WIS-S & 0.094 & 0.717 & 0.545 & 0.758 & 0.638 & 0.120 & 0.331 & 0.563 & 0.674 & 0.311 & 0.493 & 0.292 & 0.461 \\
\hline ARC & 0.244 & 0.536 & 0.595 & 0.065 & 0.435 & 0.691 & 0.863 & & & & 0.472 & & 0.488 \\
\hline ADK-A & 0.618 & 0.921 & 0.399 & 0.627 & 0.946 & 0.926 & 0.492 & 0.658 & & & & & 0.698 \\
\hline ADK-B & 0.283 & 0.698 & 0.335 & -0.032 & 0.865 & 0.902 & 0.325 & 0.621 & & & & & 0.500 \\
\hline GRN & 0.875 & 0.801 & 0.814 & 0.850 & 0.577 & 0.280 & & 0.277 & & & & & 0.639 \\
\hline VALE & 0.602 & 0.866 & 0.798 & 0.906 & 0.961 & 0.881 & 0.447 & 0.886 & & & & & 0.793 \\
\hline Total & 0.507 & 0.746 & 0.613 & 0.569 & 0.658 & 0.554 & 0.507 & 0.516 & 0.407 & 0.442 & 0.478 & 0.260 & \\
\hline
\end{tabular}

Alk, alkalinity; Cond, conductivity; DSi, dissolved reactive silica; TP, total phosphorus; TN, total nitrogen; Chl, chlorophyll a concentration, and Secc, Secchi depth. Lake chain acronyms are same as for Table 1. Blank cells are missing data.

found that synchrony of both groups of variables (nonreactive solutes and dissolved nutrients/ions) decreased with increasing WRT and increased with increasing WS:LK. However, only the relationships with the dissolved nutrient/ion variables were significant, suggesting that in longer WRT lake chains, longer residence times lead to higher processing of these variables, and more differences among lakes within a chain.

\section{DisCUSSION}

We have gained new insight into the spatial and temporal patterns of lakes across the landscape within and among lake districts. At the scale of the lake chain itself, many spatial patterns in lake variables appear to be driven by landscape position as measured simply by lake chain number, but temporal patterns are not, except in a few cases. At 
Table 3. Regressions of Lake Pair Synchrony versus Difference in the Lake Number (of the Lake Pair) per Chain

\begin{tabular}{|c|c|c|c|c|c|c|c|c|c|c|c|c|c|}
\hline \multirow{2}{*}{$\begin{array}{l}\text { Lake } \\
\text { Chain }\end{array}$} & \multicolumn{4}{|c|}{ Weathering Variables } & \multicolumn{4}{|c|}{ Dissolved Nutrients and Ions } & \multicolumn{4}{|c|}{ Total Nutrients and Water Clarity } & \multirow{2}{*}{$\begin{array}{l}\text { Total } \\
(\%)\end{array}$} \\
\hline & Alk & Cond & $\mathrm{pH}$ & $\mathrm{Ca}$ & $\mathrm{SO}_{4}$ & $\mathrm{NO}_{3}-\mathrm{N}$ & $\mathrm{NH}_{4}-\mathrm{N}$ & DSi & TP & TN & Chl & Secc & \\
\hline WIS-N & $a$ & ns & + & a & ns & ns & + & ns & ns & ns & ns & ns & 17 \\
\hline WIS-S & ns & $b$ & ns & + & ns & ns & ns & ns & + & ns & ns & ns & 8 \\
\hline $\mathrm{ARC}$ & ns & ns & ns & c & ns & + & + & & & & ns & & 13 \\
\hline ADK-A & + & + & ns & + & + & + & ns & + & & & & & 0 \\
\hline ADK-B & ns & + & ns & ns & + & + & ns & + & & & & & 0 \\
\hline GRN & + & + & + & + & + & ns & & ns & & & & & 0 \\
\hline VALE & + & + & + & + & + & + & + & + & & & & & 0 \\
\hline Total $(\%)$ & 14 & 14 & 0 & 29 & 0 & 0 & 0 & 0 & 0 & 0 & 0 & 0 & \\
\hline
\end{tabular}

ns, nonsignificant. + indicates that there is no relationship between lake number difference and average synchrony, but that synchrony for all lake pairs is high, and the majority of lake pair coherence values are $>0.50$. Negative synchrony values were treated as if synchrony were 0 and were not used to develop the regression equations. Percentages in the TOT columns represent the percent significant regressions ( $\mathrm{P} \leq 0.10)$ with lake chain number difference. Alk, alkalinity; Cond, conductivity; DSi, dissolved reactive silica; TP, total phosphorus; TN, total nitrogen; Chl, chlorophyll a concentration; Secc, Secchi depth. Lake chain acronyms are same as for Table 1. Blank cells are missing data.

${ }^{a} \mathrm{P} \leq 0.01$.

${ }^{b} \mathrm{P} \leq 0.10$.

$c \mathrm{P} \leq 0.001$.

Weathering variables
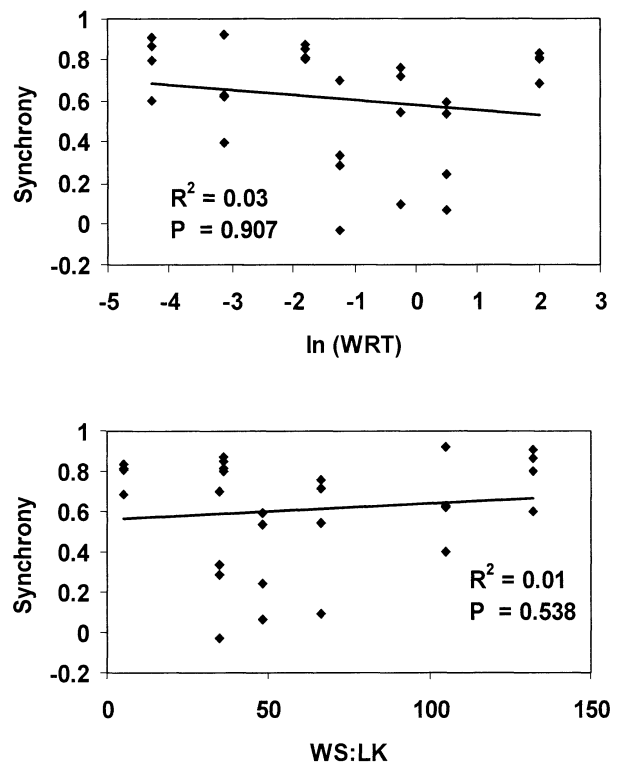

Dissolved nutrients and ions
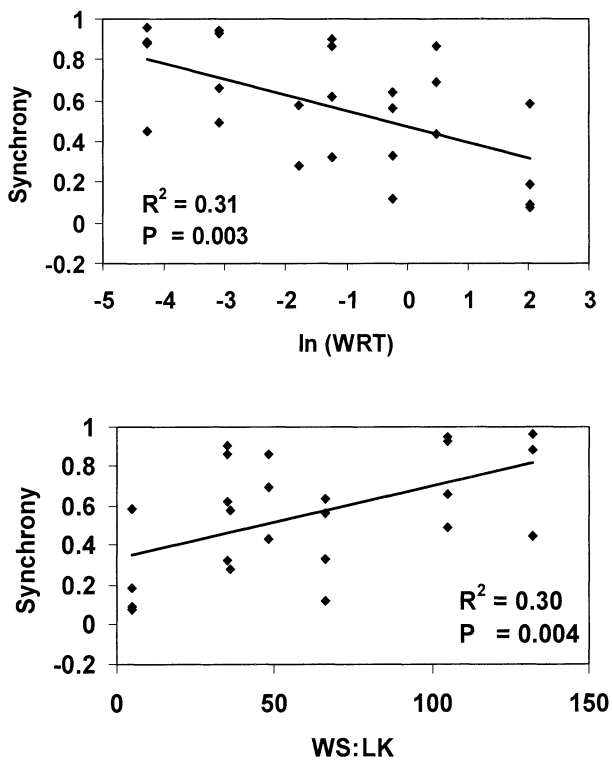

Figure 6. Average synchrony $(r)$ of each variable within a group versus logtransformed median lake chain water residence time [Ln (WRT), yr] and versus median lake chain watershed to lake area ratio (WS:LK, unitless). In the first panel, the four weathering variables for each lake chain are plotted. In the second panel, the four dissolved nutrient and ion variables are plotted. the scale of comparisons across different lake districts, however, lake chain temporal dynamics measured by average lake chain synchrony is influenced by hydrologic differences among lake chains, as measured by average WRT. We explore the significance of these findings below.

\section{Lake Chain Spatial Patterns}

The patterns observed in nine diverse lake chains support our contention that lake districts are spatially organized by position within a flow system. However, we were concerned that lake morphom- etry would covary with lake number, thus confounding the effects of landscape position. Indeed, when examining lake landscape position across hundreds of lakes within a single lake district, Riera and others (forthcoming) found lake morphometry to vary gradually with landscape position. In our analysis, however, lake morphometry did not change predictably with lake number, thus morphometric patterns generally were not responsible for the observed spatial patterns. It is important to note, however, that this general lack of a clear pattern may be due to the limitations of our data, because we focused on 
only one lake chain per lake district (except for two sites), and often only a portion of the complete lake chain.

We found a surprisingly large number of common patterns in a wide range of variables and found that differences in hydrologic setting (WRT in particular) among lake districts had fewer effects on spatial patterns in lake variables than we expected. In general, nonreactive variables, such as those subject to weathering, increased with increasing lake number, and patterns were not related to WRT. Exceptions occurred either where geologic heterogeneity was large relative to lake chain length and had an overriding influence on interlake variability (ADK-A and ADK-B) or where products of weathering were already high (WIS-S). For the more reactive solutes, such as dissolved nutrients and ions, we found fewer patterns that could be explained with our data. However, we found surprisingly common patterns for total nutrient (TP and TN) and algal (chlorophyll) variables, which increased with lake number, with the exception of the lake chain (WIS-N) where groundwater flow was the dominant hydrologic flowpath between lakes, and the arctic lake chain. We expected fairly reactive variables such as these to either show no pattern or to decrease with increasing lake number due to the high retention of nutrients that is known to occur in lakes (Rechkow and Chapra 1983). Finally, water clarity was strongly related to lake number, reflecting changes in chlorophyll, turbidity, or DOC, all of which appear to be associated with landscape position. The generality of these spatial patterns should help account for some of the unexplained among lake variability that is observed within lake districts. In addition, these results suggest that certain features of the landscape position concept are robust enough to span a wide range of seemingly disparate lake types.

Although the presence of spatial patterns was similar across lake chains, we did see differences in the strength of the patterns related to hydrogeomorphic setting and land use. Across lake chains, spatial patterns were strongest where there was a gradient in weatherable soils (GRN), strong gradients across geologic boundaries (ADK-B, although the trends were opposite from others), or long, slow flowpaths through groundwater (WIS-N). For example, the steep elevational gradient of GRN is associated with changes in geologic and soil conditions along the chain that lead to strong gradients in weathering, dissolved nutrient, and ion levels. Both QUA and WIS-S chains have land-use patterns that may lead to some of the observed patterns, especially in dissolved and total nutrients, chlorophyll, and Sec- chi depth. Finally, in TVA, it is not surprising that there were strong spatial patterns across such a long chain of reservoirs that are tightly linked hydrologically, although we cannot explain the patterns given our data. In contrast, spatial patterns were weakest where there was little weatherable material on the landscape, resulting in very dilute lakes (ADK-A and VALE). These results suggest that although it is important to recognize the tight coupling of aquatic ecosystems with their surrounding landscape, the strength of this interaction varies along geologic and hydrologic gradients among lakes districts.

\section{Lake Chain Temporal Patterns}

Synchrony is a measure of the degree to which lake pairs within a lake district behave similarly through time (Magnuson and others 1990). High synchrony is generated when lakes respond similarly to a common driver. However, for synchrony to be detected, lakes must vary through time at the temporal scale of the synchrony measure (in our case, annual). In other words, if a particular constituent does not change through time, the correlation coefficient (our measure of synchrony) between the two lakes will be low. For lakes, climate is one of the more important drivers that lead to high synchrony (Magnuson and others 1990; Webster and others forthcoming). Thus, in this analysis, lake chains with high synchrony are likely being strongly driven by a climatic driver that varies on an annual scale. For example, snowmelt is recognized as being one of the major drivers determining interannual and seasonal dynamics in two of the lake districts, the Rocky Mountain lakes and the Adirondack Region lakes (Driscoll and others 1987; Baron 1992; Campbell and others 1995). Although other strong climatic or regional drivers of lakes have been identified from other studies (that is, droughts, El Nino, atmospheric deposition), their role in determining synchrony is only beginning to be explored (Dillon and others 1997; Webster and others forthcoming).

Because of the strong spatial patterns observed in most lake chains, we expected synchrony within lake chains to also be related to landscape position. This was not the case, and synchrony was related to landscape position only for some weathering variables and only in those lake chains with average WRTs close to $1 \mathrm{y}$ and with large ranges among the lakes. Surprisingly, for many lake chains and variables, average synchrony among most lakes in the chain was high. It is important to note that any measure of synchrony is going to be strongly scale dependent. Because we have measured synchrony at the annual scale, our conclusions are most appropriate at that scale. It is likely that at other temporal 
scales, other factors than the ones identified here could influence synchrony (Baines and others 1999). Further analysis of synchrony calculated at additional temporal scales is clearly needed.

\section{A Landscape Perspective for Lakes}

Our analysis suggests that a landscape perspective for lakes based on landscape position is surprisingly robust. Although these ideas initially evolved in the groundwater dominated setting of northern Wisconsin, we found that the concept generally was applicable to a variety of hydrogeomorphic settings, from low-till subalpine lakes to midcontinent reservoirs. Our results indicate that lake ecosystems should be viewed in a spatial context across the landscape. We have addressed the spatial organization of lake districts through a landscape view that is longitudinal and that uses surface and subsurface flowpaths as a gradient that drives lake variability in addition to the known drivers of lake variability that include geology (till depth and spatial heterogeneity), land use, and hydrology (water residence times and surface vs groundwater flow). Our discovery of common patterns in such disparate settings suggests this is a fruitful area for future research.

The strength of using lake number as a metric for landscape position is its simplicity and its ability to capture variability of a whole suite of lake characteristics. However, this strength is also a weakness and limits its use in some key ways. First, the landscape position concept could benefit from considering a more realistic model of lake networks as dendritic rather than longitudinal. The importance of this distinction recently has been recognized for both streams (Fisher 1997) and lakes (Riera and others forthcoming). The lake order scheme used by Riera and others (forthcoming), analogous to stream order, is one way to improve on lake number because it incorporates inputs from multiple stream and lake sources. Second, we have assumed that patterns along lake chains are gradual, an assumption that clearly was not universal. Discontinuities along lake chains may be caused by lakes that "reset" the spatial template and represent important sinks or sources of material to downchain lakes. Third, much work remains to be done to map biological communities and ecosystem-level processes onto these spatial templates of hydrology, water flow, morphometry, and chemical and nutrient composition. Applications of the principles of biogeography clearly could benefit from this landscape approach (Magnuson and others 1998; Lewis and Magnuson forthcoming). Finally, we have limited our analysis of synchrony to the annual time scale. Resolution of the data at different time scales better suited to the water residence time of the faster flushing systems should provide interesting insights. Although our results presented here are promising, further refinements of the landscape position idea are clearly needed.

Although limnologists have long been interested in regional patterns in lake attributes, only recently have they considered lakes as connected and organized across the landscape, rather than as spatially independent entities. In this way, the concept of lake landscape position pays obvious homage to the River Continuum Concept (Vannote and others 1980). But, rather than borrow the mechanisms and detailed predictions from this concept, we borrow primarily the perspective of examining spatial relationships among aquatic ecosystems and their surrounding landscape. Hierarchically ordered systems of streams and lakes result from spatial processes that occur at broad landscape scales. Both concepts describe the position of lakes or streams along the flowpath of water moving from upland to lowland reaches within medium to large watersheds. Also, both address the complex interactions between internal and external factors influencing aquatic processes, which change in relative strength from upstream to downstream. One of the major differences between these two concepts may lie in the vastly different WRTs of lakes and streams, which are quantified and perceived of differently by lake and stream ecologists. For example, a nutrient residence time in lakes may be analogous to a nutrient spiral length in streams (Newbold and others 1982). Other analogies between different concepts for lakes and streams may be fruitful to explore as well. Interestingly, a reservoir lake chain may represent some intermediate between these two concepts and suggests that comparative studies and paradigms that span the distinctions between lake, reservoir, and stream ecosystems may be possible (for example, see Soballe and Kimmel 1987).

\section{Future Directions for Spatial Analyses of Lake Ecosystems}

Our analysis promotes the perspective of lake ecosystems imbedded in a landscape matrix interacting with each other and with other terrestrial and aquatic ecosystems. In this context, the landscape position idea not only can but should incorporate other aquatic ecosystems into its framework. We have treated streams and groundwater connections as functioning essentially as nonreactive material conduits (but see Kling and others forthcoming), which is clearly an oversimplification of the actual processes occurring. At larger spatial scales, it is 
obvious that lakes, streams, and wetlands often are connected spatially and functionally, and, in fact, the distinctions between them sometimes can even be difficult to discern. Unfortunately, with only a few exceptions, these aquatic ecosystems currently are being studied as isolated entities as reflected in the separate journals, conferences, and scientific societies that each subdiscipline uses (Lewis and others 1995; Gorham 1996). And, in the few cases where more than one ecosystem type has been studied (usually only two), it is usually to examine the effect of one on the other (Gorham 1996), rather than to integrate both into a single conceptual framework.

There are two major needs in the immediate future, one concerns data and the other concerns concepts. The data needs are to quantify the major processes and fluxes of material between all components that include lakes, streams, wetlands, and land, all put in a mass-balance context. In our study, we have examined the question of spatial processes among lakes only using the mass-balance model conceptually. Unfortunately, we could not quantify the major fluxes or compartments to solve the mass-balance equations, and we only were able to infer process from pattern. We are aware of only one study that has adequate data to at least examine the processing that occurs between lakes and connecting streams (Kling and others forthcoming), which is an important next step. Having the above information, we should be able to develop new concepts that address how the "patterns" of freshwater ecosystems (for example, lake features, connections to other aquatic ecosystems, corridors, etc.) influence the "processes" in them (primary production, nutrient cycling, community dynamics, etc.) across a wide range of spatial scales. There are many tools, approaches, and perspectives available from the discipline of landscape ecology that may help aquatic ecologists unify the study of aquatic ecosystems, at least at the landscape scale (Turner 1989; Fisher 1994; Magnuson and Kratz and others). This need for a comprehensive perspective is critical not only to integrate the science of freshwater ecology but also to aid in the management, conservation, and restoration of aquatic ecosystems.

\section{ACKNOWLEDGEMENTS}

This article is a result of a National Science Foundation (NSF)—sponsored Long Term Ecological Research Intersite comparison workshop "Ecological Variability and Organization of Lake Districts" held 5-7 February 1997 at the University of Wisconsin Trout Lake Station. We thank all participants at the workshop for dynamic and fruitful discussions that led to this synthesis. In addition, thanks to J.J. Magnuson and S.B. Baines for additional discussions and insights on these ideas. Helpful reviews of earlier drafts were provided by M. Bremigan, K. Cheruvelil, S. Nelson, O. Sarnelle, S. Walsh, and two anonymous reviewers. In addition, we thank the many workers who have contributed to the collection of these extensive databases, and we thank the following personnel in particular. PAS thanks B.J. Benson and S.B. Baines with help with data retrieval of WIS-N data. D.S.W. thanks K. Johnston for help with retrieval of TVA data. P.A.B. thanks C. Driscoll and W. Kretser (Adirondack Lakes Survey Corporation) for providing access to Adirondack long-term monitoring data. J.S.B. thanks E. Allstott and M. Bashkin for help with data retrieval of VALE data. G.W.K. acknowledges G. Kipphut, W.J. O'Brien, M. Miller, and NSF grants 9211775 , 9615949, and 9553064 for ARC data. Research by P.R.L. was supported by the Natural Sciences and Engineering Research Council of Canada, the Department of Fisheries and Oceans, and SaskWater Corporation.

\section{REFERENCES}

Baines SB, Webster KE, Kratz TK, Carpenter SR, Magnuson JJ. Synchronous behavior of temperature, calcium and chlorophyll in lakes of northern Wisconsin. Ecology. Forthcoming.

Baron J, editor. 1992. Biogeochemistry of a subalpine ecosystem: Loch Vale watershed. New York: Springer-Verlag. 247 pp.

Baron JS, Bricker OP. 1987. Hydrologic and chemical flux in Loch Vale Watershed, Rocky Mountain National Park. In: Averett RC, McKnight DM, editors. Chemical quality of water and the hydrologic cycle. Ann Arbor, MI: Lewis Publishers.

Baron JS, Caine N. The temporal coherence of two alpine lake basins of the Colorado front range. USA Freshwater Biol. Forthcoming

Birge EA, Juday C. 1911. The inland lakes of Wisconsin: the dissolved gases of the water and their biological significance. Wisconsin Geol Nat Hist Bull 22:

Campbell DH, Clow DW, Ingersoll GP, Mast MA, Spahr NE, Turk JT. 1995. Processes controlling the chemistry of two snowmeltdominated streams in the Rocky Mountains. Water Res Res 31:2811-21.

Caine N. 1995. Temporal trends in the quality of streamwater in an alpine environment: Green Lakes Valley, Colorado Front Range, U.S.A. Geographiska Annaler 77A(4):207-20.

Caine N, Thurman EM. 1990. Temporal and spatial variations in the solute content of an alpine stream, Colorado Front Range. Geomorphology 4:55-72.

Dillon PJ, Kirchner WB. 1975. The effects of geology and land use on the export of phosphorus from watersheds. Water Res 9:135-48.

Dillon PJ, Molot LA. 1996. Long-term phosphorus budgets and an examination of a steady-state mass-balance model for central Ontario. Water Res 30(10):2273-80.

Dillon PJ, Molot LA. 1997. Dissolved organic and inorganic carbon mass balances in central Ontario lakes. Biogeochemistry 36(1):29-42. 
Dillon PJ, Molot LA, Futter MN. 1997. A note on the effect of El Nino-related drought on the recovery of acidified lakes. Environ Monitoring Assess 46:105-11.

Dixit AS, Hall RI, Leavitt PR, Smol JP, Quinlan R. Effects of sequential depositional basins on lake response to urban and agricultural pollution: a paleolimnological analysis of the Qu'Appelle Valley, Saskatchewan, Canada. Freshwater Biol. Forthcoming.

Drever JI. 1982. The geochemistry of natural waters. Upper Saddle River, NJ: Prentice Hall. 388 pp.

Driscoll CT, Postek KM, Kretser W, Raynal DJ. 1995. Long-term trends in the chemistry of precipitation and lake water in the Adirondack region of New York, U.S.A. Water, Air Soil Pollut 85:583-8.

Driscoll CT, Yatsko CP, Unangst FJ. 1987. Longitudinal and temporal trends in the water chemistry of the North Branch of the Moose River. Biogeochemistry 3:37-61.

Driscoll CT, van Dreason R. 1993. Seasonal and long-term temporal patterns in the chemistry of Adirondack lakes. Water, Air, Soil Pollut 67:319-44.

Eilers JM, Glass GE, Webster KE, Rogalla JA. 1983. Hydrologic control of lake susceptibility to acidification. Can J Fish Aquat Sci 40:1896-904.

Fisher SG. 1994. Pattern, process and scale in freshwater ecosystems: some unifying thoughts. In: Hildrew A, Giller P, Rafaelli $\mathrm{D}$, editors. Pattern, process and scale in aquatic ecology. Blackwell Scientific.

Fisher SG. 1997. Creativity, idea generation, and the functional morphology of streams. J North Am Benthol Soc 16(2): 305-18.

Fisher SG, Grimm NB. 1991. Streams and disturbance: are cross-ecosystem comparisons useful? In: Cole J, Lovett G, Findlay S, editors. Comparative analyses of ecosystems. New York: Springer-Verlag. 375 pp.

Frissell CA, Liss WJ, Warren CE, Hurley MD. 1986. A hierarchical framework for stream habitat classification: viewing streams in a watershed context. Environ Manage 10(2):199-214.

Forbes SA. 1887. The lake as a microcosm. Bulletin Science Association of Peoria, IL. 1887:77-87.

Forel FA. 1892. Lac Leman: monographie limnologique. Lausanne: Rouge

Gibson CE, Wu Y, Smith SJ, Wolfe-Murphy SA. 1995. Synoptic limnology of a diverse geological region: catchment and water chemistry. Hydrobiologia 306(3):213-27.

Goldstein RA, Gherini SA, Driscoll CT, April R, Schofield CL, Chen CW. 1987. Lake-watershed acidification in the North Branch of the Moose River. Introduction. Biogeochemistry 3:5-20.

Gorham E. 1996. Wetlands: an essential component of curricula in limnology. In: Freshwater ecosystems: revitalizing educational programs in limnology. Washington, DC: National Research Council.

Hall RI, Leavitt PR, Quinlan R, Dixit AS, Smol JP. 1999. Effects of agriculture, urbanization and climate on water quality in the Northern Great Plains. Limnol Oceanogr 44:739-56.

Hall RI, Leavitt PR, Dixit AS, Quinlan R, Smol JP. Limnological succession in reservoirs: a paleolimnological comparison of two methods of reservoir formation. Can J Fish Aquat Sci. Forthcoming.

Hynes HBN. 1975. The stream and its valley. Verh Int Verein Limnol 19:1-15.
Juday C, Meloche VW. 1943. Physical and chemical evidence relating to the lake basin seal in certain areas of the Trout Lake region of Wisconsin. Trans Wis Acad Sci Arts Lett 35:157-74.

Junk WJ, Bayley PB, Sparks RE. 1989. The flood pulse concept in river-floodplain systems. In: Dodge DP, editor. Proceedings of the International Large River Symposium. Can J Fish Aquat Sci 106:110-27.

Kling GW, Kipphut GW, Miller MC. 1991. Arctic lakes and rivers as gas conduits to the atmosphere: implications for tundra carbon budgets. Science 251:298-301.

Kling GW, Kipphut GW, Miller MM, O'Brien WJ. The influence of spatial position, morphology, and downslope processing on the coherence of lake properties. Freshwater Biol. Forthcoming.

Kratz TK, Webster KE, Bowser CJ, Magnuson JJ, Benson BJ. 1997. The influence of landscape position on lakes in northern Wisconsin. Freshwater Biol 37:209-17.

Kratz TK, Soranno PA, Baines SB, Benson BJ, Magnuson JJ, Frost TM, Lathrop RC. 1998. Interannual synchronous dynamics in north temperate lakes in Wisconsin, USA. In: George DG and others, editors. Management of lakes and reservoirs during global climate change. The Netherlands: Kluwer Academic Publishers.

Lathrop RC. 1992. Nutrient loadings, lake nutrients, and water clarity. In: Kitchell JF, editor. Food web management: a case study of Lake Mendota. New York: Springer-Verlag. p 69-96.

Lathrop RC, Nehls SB, Brynildson CL, Plass KR. 1992. The fishery of the Yahara Lakes. Technical Bulletin nr 181. Department of Natural Resources, Madison, WI.

Lewis WM, Chisholm S, D’Elia C, Fee E, Hairston NG, Hobbie J, Likens GE, Threlkeld S, Wetzel R. 1995. Challenges for limnology in North America: an assessment of the discipline of the 1990s. Am Soc Limnol Oceanogr Bull 4(2):1-20.

Lewis DB, Magnuson JJ. Landscape spatial patterns in freshwater snail assemblages across Northern Highland catchments. Freshwater Biol. Forthcoming.

Likens GE. 1984. Beyond the shoreline: a watershed-ecosystem approach. Verh Int Verein Limnol 22:1-22.

Likens GE, editor. 1985. An ecosystem approach to aquatic ecology: Mirror Lake and its environment. New York: SpringerVerlag. 516 pp.

Magnuson JJ, Kratz TK. Lakes in the landscape: Approaches to regional limnology. Verh Int Verein Limnol. Forthcoming.

Magnuson JJ, Benson BJ, Kratz TK. 1990. Temporal coherence in the limnology of a suite of lakes in Wisconsin, U.S.A. Freshwater Biol 23:145-59.

Magnuson JJ, Tonn WM, Banerjee A, Toivonen J, Sanchez O, Rask M. 1998. Isolation vs. extinction in the assembly of fishes in small northern lakes. Ecology 79(8):2941-56.

Mast MA, Drever JI, Baron J. 1990. Chemical weathering in the Loch Vale Watershed, Rocky Mountain National Park, Colorado. Water Resources Res 26:2971-8.

Minshall GW, Cummins KW, Peterson RC, Cushing CE, Bruns DA, Sedell JR, Vannote RL. 1985. Developments in stream ecosystem theory. Can J Fish Aquat Sci 42:1045-55.

Molot LA, Dillon PJ. 1993. Nitrogen mass balances and denitrification rates in central Ontario lakes. Biogeochemistry 20(3): 195-212.

Newbold JD, O'Neill RV, Elwood JW, VanWinkle W. 1982. Nutrient spiraling in streams: implications for nutrient limitation and invertebrate activity. Am Nat 120:628-52. 
Omernik J. 1976. The influence of land use on stream nutrient levels. Corvallis, OR: US Environmental Protection Agency.

Reckhow KH, Chapra SC. 1983. Engineering approaches for lake management. Volume 1. Data analysis and empirical modeling. Boston: Butterworth Publishers. 340 pp.

Riera JL, Magnuson JJ, Kratz TK, Webster KE. A geomorphic template for the analysis of lake districts applied to the Northern Highland Lake District, Wisconsin, U.S.A. Freshwater Biol. Forthcoming.

Rochelle BP, Liff CI, Campbell WG, Cassell DL, Church MR, Nusz RA. 1989. Regional relationships between geomorphic/ hydrologic parameters and surface water chemistry relative to acidic deposition. J Hydrology 1 12:103-20.

Schindler DW, Beaty KG, Fee EJ, Cruikshank DJ, DeBruyn ED, Findlay DL, Linsey GA, Shearer JA, Stainton MP, Turner MA. 1990. Effects of climatic warming on lakes of the central boreal forest. Science 250:967-70.

Schindler DW, Curtis PJ, Bayley SE, Parker BR, Beaty KG, Stainton MP. 1997. Climate-induced changes in the dissolved organic carbon budgets of boreal lakes. Biogeochemistry 36(1): 9-28.

Soballe DM, Kimmel BL. 1987. A large-scale comparison of factors influencing phytoplankton abundance in rivers, lakes, and impoundments. Ecology 68(6):1943-54.

Turner MG, Gardner RH. 1989. Quantitative methods in landscape ecology. New York: Springer-Verlag.
Vannote RL, Minshall GW, Cummins KW, Sedell JR, Cushing CE. 1980. The river continuum concept. Can J Fish Aquat Sci 37:130-7.

Vollenweider RA. 1969. Possibilities and limits of elementary models concerning the budget of substances in lakes. Arch Hydrobiol 66(1):1-36.

Ward JV, Stanford JA. 1983. The serial discontinuity concept of lotic ecosystems. In: Fontaine TD, Bartell SM, editors. Dynamics of lotic ecosystems. Ann Arbor Science Publishers. 494 pp.

Webster KE, Kratz TK, Bowser CJ, Magnuson JJ, Rose WJ. 1996. The influence of landscape position on lake chemical responses to drought in northern Wisconsin. Limnol Oceanogr 41(5):977-84.

Webster KE, Soranno PA, Baines SB, Kratz TK, Bowser CJ, Dillon PJ, Campbell P, Fee EJ, Hecky RE. Structuring features of lake districts: geomorphic and landscape controls on lake chemical responses to drought. Freshwater Biol. Forthcoming.

Wiley MJ, Osborne LL, Larimore RW. 1990. Longitudinal structure of an agricultural prairie river system and its relationship to current stream ecosystem theory. Can J Fish Aquat Sci 47:373-83.

Windolf J, Jeppson E, Jensen JP, Kristensen P. 1996. Modelling of seasonal variation in nitrogen retention and in-lake concentration: a four-year mass balance study in 16 shallow Danish lakes. Biogeochemistry 33(1):25-44.

Winter TC. 1977. Classification of the hydrologic settings of lakes in the North Central United States. Water Resources Res 13(4):753-67. 